\title{
TURLOUGHS: A MOSAIC OF BIODIVERSITY AND MANAGEMENT SYSTEMS UNIQUE TO IRELAND
}

\author{
TURLOUGH: MOZAIK BIOLOŠKE RAZNOVRSTNOSTI IN NAČIN \\ GOSPODARJENJA, EDINSTVEN ZA IRSKO
}

\author{
Micheline SHEEHY SKEFFINGTON ${ }^{1}$ \& Mike GORMALLY ${ }^{2}$
}

\begin{abstract}
UDC 911.2:556.166(417)

Sheehy Skeffington M. J. \& Gormally, M.: Turloughs: a mosaic of biodiversity and management systems unique to Ireland

Turloughs are seasonally flooded karst wetlands in Ireland and as priority habitats under the EU Habitats Directive, many have been designated as Special Areas of Conservation. They flood usually in winter, mostly through swallow holes, or estavelles, that open to the underlying limestone, but they may fill at any time of year if rainfall is excessive. Almost all of them occur on well-bedded pure Carboniferous limestone.

Since the shallow basins of turloughs are usually covered in vegetation, unlike more permanent water bodies, they are excellent feeding areas for over-wintering wildfowl, such as ducks, geese and swans, hosting numbers of international importance. Turloughs are almost all grazed by domestic livestock in the summer months and they support relatively low-intensity farming due to their marginal nature and inaccessibility for much of the year. The vegetation depends to a large extent on the flooding regime and on soil type, usually comprising small-sedge communities or grass-dominated swards. The type of management varies considerably, not only between, but within turloughs. This gives rise to a diversity of sward composition and structure that increases both plant and invertebrate diversity. Whereas drainage was a large threat to turlough conservation in the past, eutrophication of flood waters is gaining in importance. However, the single greatest threat to turlough biodiversity in the future may be the cessation of farming within their basins. Turloughs are an integral part of the Irish cultural landscape and so it is important to develop a strategy for turlough conservation that involves the land-owners and takes into account local socio-economic factors as well as the conservation of their biodiversity.

Key words: turloughs, wetland, seasonal flooding, biodiversity, management, grazing, Ireland.
\end{abstract}

Izvleček

UDC 911.2:556.166(417)

Sheehy Skeffington M. J. \& Mike Gormally: Turlough: mozaik biološke raznovrstnosti in način gospodarjenja, edinstven za irsko

Turlough je sezonsko poplavljeno mokrišče na Irskem in kot prednostni habitat pod EU Direktivo za habitate. Številni turloughi so tudi označeni kot Posebno varstveno področje. Turloughi so običajno poplavljeni pozimi, voda jih zalije skozi požiralnike - estavele, ki se odpirajo v podlagi iz apnenca. Če je dežja preveč, se lahko napolnijo $\mathrm{z}$ vodo ob kateremkoli letnem času. Skoraj vsi so na plastovitem karbonskem apnencu. Ker so te plitve kotanje ali turloghi običajno porasli, medtem ko stalna vodna telesa niso, so izvrstna pasišča in krmišča za prezimujoče vodne ptice, kot so race, gosi in labodi, katerih število je mednarodno pomembno. Skoraj vsi turloughi so v poletnih mesecih pašniki za živino, a le v okviru ekstenzivne reje, saj so obrobnega pomena in velik del leta nedostopni. Rastlinstvo je v veliki meri odvisno od poplavnega režima in tipa prsti; v glavnem gre za skupnost malega šaša ali za travnike. Način gospodarjenja je zelo različen, ne le med posameznimi turloughi, ampak tudi na posameznem turloughu. Zaradi tega so nastali zelo različni travniki, tako po sestavi kot po strukturi, kar pospešuje tako rastlinsko raznovrstnost kot tudi raznovrstnost nevretenčarjev. Medtem ko je bilo osuševanje nekdaj največja nevarnost za turloughe, postaja danes najpomembnejša evtrofikacija poplavne vode. Vendar pa bo v bodoče največja grožnja biološki raznovrstnosti teh kotanj prenehanje njihove izrabe v kmetijske namene. Turloughi so sestavni del irske kulturne pokrajine in je torej pomembno določiti ukrepe za njihovo ohranitev, ki bodo vključevali lastnike zemlje in upoštevali tako družbenoekonomske dejavnike kot tudi ohranjanje njihove biološke raznovrstnosti.

Ključne besede: turlough, mokrišče, sezonska poplava, biološka raznovrstnost, gospodarjenje, paša, Irska.

\footnotetext{
${ }^{1}$ Department of Botany, NUI, Galway, Galway, Ireland

${ }^{2}$ Applied Ecology Unit, Centre for Environmental Science, NUI, Galway, Galway, Ireland;

e-mail: micheline.sheehy@nuigalway.ie; mike.gormally@nuigalway.ie
}

Received/Prejeto: 21.06.2006 


\section{INTRODUCTION}

Turloughs are karst basins that occur where Carboniferous limestone is exposed or near the surface and where, with high rainfall, groundwater eventually flows out into the basin through springs or estavelles (swallow holes that also act as springs) (Coxon 1987a, b). Turloughs are relatively shallow basins, a majority flooding to 1-3 m depth in winter (Coxon 1987b). They support vegetation and/or soils characteristic of wetlands (Working Group on Groundwater 2004). The limestone in which they occur is almost always a very pure Dinantian bedded limestone (Sheehy Skeffington et al. 2006). They are a feature of Ireland as not only are there extensive areas of low-lying exposed limestone, but high rainfall $(>1,000 \mathrm{~mm}$ in the western $2 / 3$ of the country) falls throughout the year (>150 rain days per year) (Collins \& Cummins 1996). Turloughs fill mostly in the winter months (October to April), but may also fill during times of persistent heavy rainfall, as in August-October 2001 (Moran et al. 2000) and May 2006.

Since most turloughs drain for at least 5 months during the summer, the basin floors support a range of plant communities, from dry grassland at the edge to wetland communities in the main basin and aquatic vegetation in wetter turloughs (O'Connell et al. 1984; Goodwillie 1992, 2003). The summer-accessible grassland has long been valued as pasture, and grazing by domestic stock is likely to prevent encroachment by scrub in the upper reaches of the basin, whereas flooding prevents trees from spreading to the centre (Praeger 1932; Goodwillie 2003). The name is an Irish term and opinions differ concerning its origins, but here we follow that suggested by Joyce (1869), with -lough as a corruption of the suffix -lach (the current Irish spelling is turlach) that would mean the word refers to a place that dries out (tur $=$ dry), not a 'dry lake' (lough means lake). This interpretation puts greater emphasis on the fact that the place dries out. This is in keeping with the fact that any such place would have always been valued for use as summer pasture.

Turloughs are almost unique to Ireland (there is one in Wales - Campbell et al. 1992) and have priority status under the Habitats Directive (EEC 1992). A total of 71 turloughs have SAC status and nine of these are also SPAs, as many turloughs are important winter feeding habitats for wildfowl that benefit from the full vegetation cover under the shallow water (Ruttledge 1989; Cabot 1999; Sheehy Skeffington et al., 2006). A large proportion of the whooper swans Cygnus cygnus which overwinter in Britain and Ireland can be found on turloughs (Robinson et al. 2004).

Turloughs vary in size from 1 ha or less to over 250 ha. Whereas many of those $>10$ ha have been de- scribed in detail, including their area, (Coxon 1987a, b; Goodwillie 1992), many more exist that are smaller than this. To date over 300 active turloughs have been documented and the size of about 100 is known (Goodwillie et al. 1997; Sheehy Skeffington et al. 2006). Of these, the biggest number are $<10$ ha and many more fall within the 20-40 ha size category (Fig. 1). However, it is likely that a majority of those for which the size is not known are $<10$ ha, since, due to their small size, they have not been fully documented. Following drainage schemes from the end of the 20th century, only one turlough larger than 200 ha remains. Originally the biggest turlough was Turloughmore (which means 'big turlough') which extended to approximately 400 ha (D’Arcy 1983).

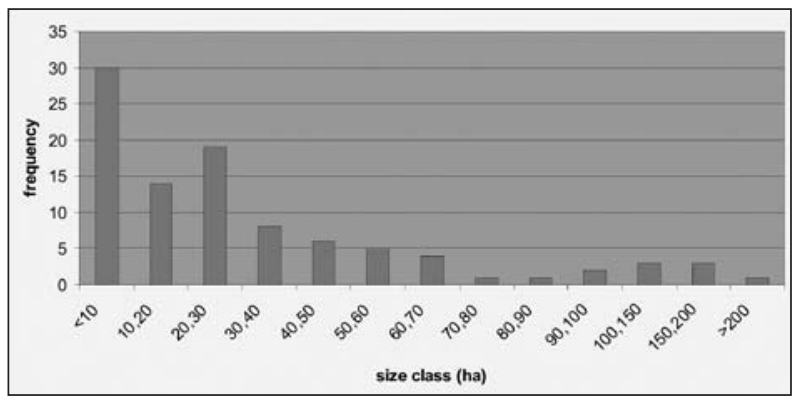

Fig. 1: Turlough size for 97 turloughs for which the area is known. Data from Goodwillie et al. (1997) and Sheehy Skeffington et al. (2006).

The plant communities of turloughs are relatively well documented (Goodwillie 1992; Goodwillie et al. 1997; Goodwillie 2003) and they usually form concentric zones around the turlough basin as a function of depth and duration of flooding (Fig. 2 and also Moran et al. 2008). A total of 24 main plant communities have been described for the turloughs surveyed (Goodwillie 2003), which can be classified into two major phytosociological classes, the Scheuzerio-Caricetea fuscae, and the Plantaginetea majoris (Ivimey-Cook \& Proctor 1966; O'Connell et al., 1984). The occurrence of the former (usually sedge-dominated communities) is associated with greater soil moisture and peat formation, whereas the latter is characterised by grasses and species such as Potentilla anserina and predominates on more mineral soils (O’Connell et al. 1984; Ní Bhriain et al. 2002; Regan, et. al., 2007, Moran et al., 2008).

To date, most ecological research on turlough invertebrates has been on the aquatic communities (see e.g. Reynolds 1996; 2000; 2003) and the terrestrial turlough invertebrates have received only sporadic attention (see, however, Owen 1997; Good \& Butler 2001; reviewed in 
Sheehy Skeffington et al., 2006). But the salient results of this research indicate that turloughs harbour a number of rare terrestrial invertebrate species and that the aquatic communities, due to the ephemeral nature of the habitat, are also unusual, if relatively species-poor. The rarity of the invertebrates is partly due to the disappearance in Europe of wetland habitats, whereas Ireland still retains a large proportion of relatively intact wetlands (EEA 2004a). But crucial to their conservation is also the relative low-intensity of land use, not only on turloughs, but of the adjacent land (Good \& Butler 2001; Bond 1997). In recent times, therefore, focus has been on the relationship between turlough land use and plant and invertebrate communities (Ní Bhriain et al., 2002, 2003; Moran 2005; Regan 2005; Ryder et al., 2005).

\section{TURLOUGHS AS CULTURAL LANDSCAPES}

With current reforms of the EU Common Agricultural Policy (CAP), there is an increasing need to be aware of their effects on the farming community in so-called 'marginal' lands. Such farming practices are extensive, with high labour but low chemical or mechanical inputs. These practices are not only intrinsically part of any national heritage, they are vital for the conservation of plant and invertebrate communities and even birds that feed on them (Bignal \& McCracken 1996; EEA 2004b). As Ireland will lose its Objective 1 status in 2007, it is important to set up ways of encouraging farmers to remain on 'marginal' land, including turloughs, before that knowledge is lost or the land is abandoned.

Turloughs have mostly been managed as pasture, though in times of need they have been used for tillage (Aughney \& Gormally 1999), occasionally with small plots for potatoes. Former cultivation ridges are still found around the margins of turloughs today. The whole system of turlough management can be seen on the old (1870s) 6 inch to a mile (1:10560) maps, where all the field boundaries are visible. Around turloughs, these generally form a pattern radiating out from the centre of the turlough basin (Fig. 2). In many cases, the central basin is managed as commonage with land-owners adjacent to or near the turlough having grazing rights. These rights can either relate to an exact amount of stock (grazing units in Ireland are sometimes known as 'collops', approximately equivalent to Livestock Units (1L.U. = 1 horse or adult cow)), or more commonly, it is agreed informally amongst the shareholders, who generally know the relative amount of stock their particular turlough can support.

Most land-owners graze cattle (dairy and beef animals) on turloughs (Aughney \& Gormally 1999) but sheep are also found, as are horses, donkeys and even domestic geese (Feehan 1998; Aughney \& Gormally 1999). Too early use of the turlough after the flood recedes, especially with heavy animals, is avoided, as this causes much poaching and damage to the vegetation. However, trampling and bare ground, with associated ruderal plants, are often a feature especially of the turloughs on more mineral soils (Goodwillie 1992; 2003).

For many turloughs, most local land-owners have land immediately adjoining the commonage, with the fields radiating out from the central basin (Fig. 2). In turloughs where there is no commonage, individual fields stretch right across the basin, traversing several flood zones and therefore vegetation bands (e.g. Moran et al., 2008). The reason for this pattern of land use is connected not so much with an equal distribution amongst the community of land and vegetation type, but with the ready accessibility of water. This was particularly important before the advent of rural water schemes in Ireland in the 1950s, as the supply of water for stock was difficult. Farmers still ferry large containers of water from a turlough to stock, while water is still present in the turlough basin.

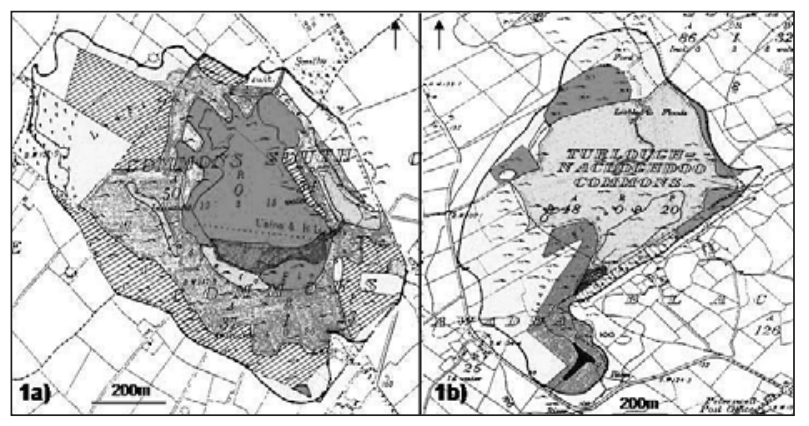

Fig. 2: Two turloughs in counties Longford and Galway showing vegetation patterns relating to flood duration. 1a) the entire basin is commonage, with fields radiating out from it; 1b) part of basin is commonage, the other part consists of radiating fields. Maps with permission from Goodwillie (1992).

The pattern of land use is primarily a function of flooding period (hydroperiod) with a farmer letting stock out onto the turlough as the flood subsides. The lower edge of the winter fields is usually the median upper limit of winter flooding (Fig. 3: the SAC boundary between the sets of fields in the southern part of the turlough follows 


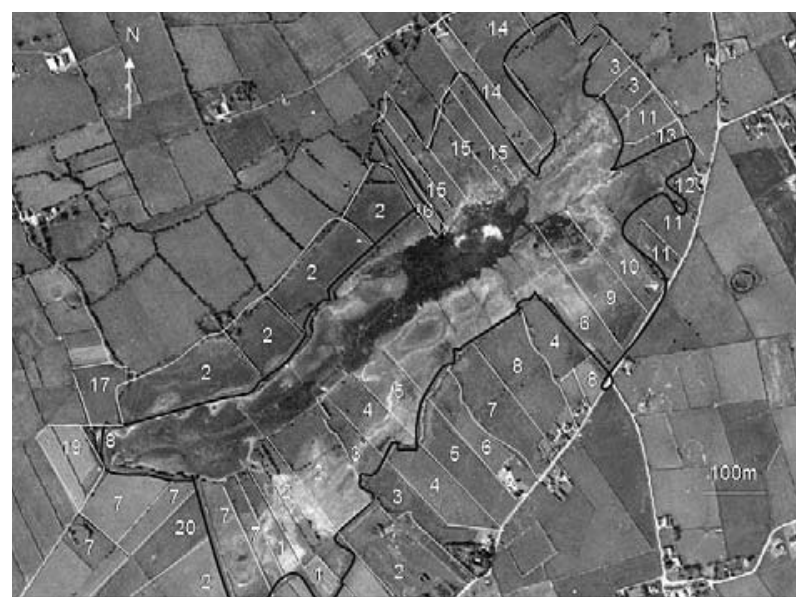

this). Access through this wall or hedge is usually via a gate to the adjacent high water for drinking. These fields provide grazing with water access through the times of highest flood (usually November-February). In exceptionally high flood, the lower portion of the field can be flooded, reducing the area of available grass, but continu-
Fig. 3: Ballinacourty turlough in SE Galway, indicating fields radiating out from central basin. Each field is numbered according to land ownership, where each number refers to a different owner/ farmer. The fields to the NW (of which the turlough ones are marked '2') were originally those of the local land-lord and are therefore bigger. The dark line, outlining the main turlough basin and some of the fields, represents the SAC boundary. The central basin is made up of two commonages. Some walls are no longer functional, though their outline is visible. Aerial photograph by permission from Ordnance Survey, Ireland, Government of Ireland, Copyright Permit no. MP004506.

ing to supply water. As the flood subsides through the fields in the inner basin (through May), the stock can be let out onto these and a similar system of walls may exist to keep them from the central basin -which may be commonage (Fig. 3: inner walls of fields in S and SW part of turlough divide them from the commonage). In some cases, farmers have dug a pit in the lower end of this field, thus providing water without allowing the stock into the commonage.

\section{CONSERVATION THROUGH MANAGEMENT}

In the past, almost every field around a turlough was owned by a different farmer and still today different farmers will own adjacent fields in the turlough basin (Fig. 3). What is even more striking is that each farmer frequently manages his/her fields in a different way (Feehan 1998; Ní Bhriain et al. 2003). Not only does the stocking density vary, but the time and frequency of putting the stock out in the fields can be as varied as the number of farmers owning the fields (Ní Bhriain et al. 2003). The resultant heterogeneity in plant species composition and vegetation structure is very important for the diversity of invertebrates in the turlough (Ní Bhriain et al., 2003; Moran 2005; Regan 2005).

This variety of land use within and between turlough basins is an important contribution to the biodiversity of turloughs. Thus the drawing up of management plans must take cognisance of the varied farming practices within and between turloughs and it is not possible to formulate generalised prescriptions for turlough management. Management plans need to be site specific, or there needs to be flexibility within any scheme, such as SAC prescriptions, that will allow for the individual farmers to continue their particular method of farming.

In addition, invertebrates and birds respond differently from vegetation to habitat conditions and management on turloughs and it is also necessary to bear this in mind when evaluating turloughs for conservation value. The vegetation can give an initial reference point for evaluation, but it must be followed up with more detailed surveys. In fact, evidence shows that it is important to conserve a range of sites, with a range of management systems, in order to cater for the diversity of organisms that benefit from turloughs.

\section{THREATS TO TURLOUGHS}

As with many wetlands, the main threat to turloughs is that of drainage and many have been lost in the past through this action. Drainage of Irish karst lowlands for over a century has lowered water tables and dried out turloughs, resulting in the loss of at least $50 \%$ of flooded turlough area (Drew \& Coxon 1988). Although there is an on-going issue with farmers wishing to drain land, the decline in the importance of agriculture means that 
such drainage schemes may now be less of a threat. Pollution and eutrophication are now becoming of increasing concern. In karst systems, groundwater is easily contaminated and difficult to trace, yet requires addressing under the Water Framework Directive (Working Group on Groundwater 2004). There is some evidence of catchment pollution, but also more intensively managed turloughs seem to support mesotrophic grassland, rather than the Cyperaceae-dominated swards of oligotrophic turloughs (see Sheehy Skeffington et al., 2006).

However, another threat to turlough biodiversity, if not conservation per se, is the possible cessation of small-scale traditional farming in the west of Ireland.
It is becoming increasingly clear that high nature value farmland is associated with so-called marginal land and that unless policies are devised to retain the farming community on the land, these areas will become abandoned (EEA 2004a). As most of the diversity of turloughs is intrinsically linked to the diversity of farming systems both within and between turloughs, it is important that they be included in any national plan to address high nature value farmland and its conservation. It is clear that turloughs are integrated into the human landscape yet their abandonment in favour of exploiting more accessible lands is a real possibility unless national policies specifically target them for conservation.

\section{ACKNOWLEDGEMENTS}

The authors wish to thank Nick Scott for helpful comments on the manuscript and Martin Costello for advice on farming systems around turloughs. Roger Goodwillie kindly allowed the maps in Fig. 2 to be used. Acknowledgement must also be given to the 'turlough team', who have carried out a lot of research on turloughs with the authors in recent years: James Moran, Bébhinn Ní Bhriain, Áine O Connor, Eugenie Regan and Marjolein Visser.

\section{REFERENCES}

Aughney T.C. \& Gormally M.J., 1999: Farm Habitats in Annaghdown, County Galway: Management Practices in the 1940s.- Galway. Environmental Sciences Unit, National University of Ireland, Galway. 34 pp.

Bignal, E.M. \& McCracken, D. I., 1996: Low-intensity farming systems in the conservation of the countryside.- Journal of Applied Ecology, 33 p. 413-424.

Bond, K.G.M., 1997: Insect survey. Lepidoptera. p. 1-86.In: Southern Water Global \& Jennings O'Donovan \& Partners (eds), An Investigation of the Flooding Problems in the Gort-Ardrahan Area of South Galway. Ecology Baseline Study Volume 2. Dublin. The Office of Public Works.

Cabot, D., 1999: Ireland. A Natural History.- London. The New Naturalist, Harper Collins. 512 pp.

Campbell, S. \& Gunn, J. \& Hardwick, P., 1992: Pant-yllyn -the first Welsh turlough?- Earth Science Conservation 31, 3-7.

Coxon, C.E., 1987a: The spatial distribution of turloughs.Irish Geography, 20, p. 11-23.

Coxon, C.E., 1987b: An examination of the characteristics of turloughs using multivariate statistical techniques.- Irish Geography, 20, p. 24-42.
D’Arcy G.H., 1983: Post-drainage Assessments of Impacts on a Part of the River Clare Catchment, County Galway.- MSc thesis, Trinity College, Dublin.

Drew, D.P. \& Coxon, C.E. 1988: The effects of land drainage on groundwater resources in karstic areas of Ireland.- In: Yuan Daoxian (Ed.) Proceedings of the 21st I.A.H. Congress, Geological Publishing House, Beijing, China, p. 204-209.

EEA, 2004a: The state of biological diversity in the European Union.- Stakeholders' Conference. Biodiversity and the EU -Sustaining Life, Sustaining Livelihoods. 25-27th May. Malahide, Ireland. 29 pp.

EEA, 2004b: High Nature farmland. Characteristics, trends and policy challenges.- Copenhagen. European Environment Agency.

EEC 1992. Council Directive 92/43/EEC on the conservation of natural habitats and of wild fauna and flora.- Official Journal no. L 206, 27.7.92.

Feehan, J., 1998: Traditional Management of Selected Turlough and Machair Sites.- Report to National Parks and Wildlife Service, Dublin. 
Good, J.A.\& Butler, F.T., 2001: Turlough pastures as a habitat for Staphylinidae and Carabidae (Coleoptera) in south-east Galway and north Clare, Ireland.- Bulletin of the Irish Biogeographical Society 25, p. 74-88.

Goodwillie, R., 1992: Turloughs over 10ha: Vegetation Survey and Evaluation.- Internal report to the $\mathrm{Na}$ tional Parks and Wildlife Service, Office of Public Works, Dublin.

Goodwillie, R., 2003: Vegetation of turloughs.- P. 135-144 In: Otte, M.L. (ed.) Wetlands of Ireland. Distribution, ecology, uses and economic value. Dublin. University College Dublin Press.

Goodwillie, R., Heery, S. \& Keane, S., 1997: Wetland vegetation on the Gort lowlands.- P. 1-131 In: Southern Water Global Ltd (ed.), An Investigation of the Flooding Problems in the Gort-Ardrahan Area of South Galway. Ecology Baseline Study Volume 1. Dublin. The Office of Public Works.

Ivimey-Cook, R.B. \& Proctor, M.C.F., 1966: The plant communities of the Burren, Co. Clare.- Proceedings of the Royal Irish Academy 64 (B), 211-301.

Joyce P.W., 1869: The Origin and History of Irish Names of Places.- Exact facsimile reprint (1995) of the original. Dublin. Edmund Burke, Publisher.

Moran, J., 2005: Skealoghan Turlough, County Mayo: implications of grazing and flooding regimes for plant and carabid beetle communities with reference to turlough farming systems in the region.- $\mathrm{PhD}$ thesis, Department of Botany and Environmental Science Unit, NUI, Galway.

Moran, J. \& Sheehy Skeffington, M. \& Gormally, M. 2000: Vegetation Studies on Skealoghan Turlough, Ireland (Part 2): The Influence of Hydrological Regime, Soils and Grazing Management on Plant Community Composition and Species Richness.- Applied Vegetation Science 1 (1).

Ní Bhriain, B. \& Sheehy Skeffington, M. \& Gormally, M., 2002: Conservation implications of the land use practices on the plant and carabid beetle communities of two turloughs in Co. Galway, Ireland.- Biological Conservation 1, p. 81-92.

Ní Bhriain, B. \& Gormally, M. \& Sheehy Skeffington, M., 2003: Changes in land use practices at two turloughs, on the east Burren limestones, Co. Galway, with reference to nature conservation. Biology and Environment.- Proceedings of the Royal Irish Academy 103B (3), p. 169-176.

O'Connell, M. \& Ryan, J.B. \& MacGowran, B.A., 1984: Wetland communities in Ireland: a phytosociological review,- P. 303-364 In: Moore, P.D. (ed.), European Mires. London. Academic Press.

Owen, J. A. 1997: Beetles (Coleoptera) recorded from various Irish sites in 1993, 1994 and 1996.- Bulletin of Irish Biogeographical Society, 20, p. 136-154.
Praeger, R. Ll., 1932: The flora of the turloughs: a preliminary note.- Proceedings of the Royal Irish Academy $41 \mathrm{~B}$, p. 37-45.

Regan, E. C., 2005: An Investigation of the Plant, Carabid and Staphylinid Communities of Turloughs in Southeast Galway/NorthClare, Ireland.- PhD thesis, Department of Botany and Environmental Science Unit, NUI, Galway.

Regan, E.C., Sheehy Skeffington, M. and Gormally M.J. 2007: Wetland plant communities of turloughs in southeast Galway/north Clare, Ireland in relation to environmental factors.- Aquatic Botany Volume 87 (1), p. 22-30.

Reynolds, J.D., 1996: Turloughs, their significance and possibilities for conservation.- P. 38-46 In: Reynolds, J.D. (ed.), The Conservation of Aquatic Systems. Dublin. Royal Irish Academy.

Reynolds, J.D., 2000: Invertebrate communities of turloughs (temporary lakes) in south-east Galway, Ireland.- Verhandlungen Internationale Vereinigung für Thoretische und Angewandte Limnologie, 27 (3), p. 1679-1684.

Reynolds, J.D., 2003: Fauna of turloughs and other wetlands.- P. 145-156 In: Otte, M.L. (ed.) Wetlands of Ireland. Distribution, ecology, uses and economic value. Dublin. University College Dublin Press.

Robinson, J.A. \& K. Colhoun \& J.G. McElwaine \& Rees, E.C., 2004: Whooper Swan Cygnus cygnus (Iceland population) in Britain and Ireland 1960/61 - 1999/ 2000.- Waterbird Review Series. Slimbridge. The Wildfowl and Wetlands Trust/ Joint Nature Conservation Committee.

Ruttledge, R. F., 1989: Birds in Counties Galway and Mayo.- Dublin. Irish Wildbird Conservancy. 100 pp.

Ryder, C. \& J. Moran, \& R. McDonnell \& M. Gormally 2005: Conservation implications of grazing practices on the plant and dipteran communities of a turlough in Co. Mayo, Ireland.- Biodiversity and Conservation, 14, p. 187-186.

Sheehy Skeffington M. \& J. Moran, \& Á. O Connor \& E. Regan \& C. E. Coxon \& N. E. Scott, \& M. Gormally, (2006): Turloughs - Ireland's unique wetland habitat.- Biological Conservation 133 (3), p. 265-290.

Working Group on Groundwater, 2004: Guidance on the assessment of pressures and impacts on groundwater dependent terrestrial ecosystems, Risk Assessment Sheet GWDTERA2a - Risk to Turloughs from Phosphate.- Water Framework Directive Pressures and Impacts Assessment Methodology, Guidance Document no.GW9. Dublin. Working Group on Groundwater, Sub-committee on Turloughs. Environment Protection Agency. 